\title{
Investigating Micrometeorological Differences between Saline Steppe, Forest-steppe and Forest Environments in Northern Serbia during a Clear and Sunny Autumn Day
}

\author{
Dragan D. Milošević ${ }^{A}, B$, Jelena Dunjić ${ }^{B}$, Vladimir Stojanović ${ }^{B}$ \\ Received: March 28, 2020 | Revised: July 07, 2020 | Accepted: July 24, 2020 \\ doi: 10.5937/gp24-25885
}

\begin{abstract}
Saline habitats of the Pannonian plain are specific regarding their extraordinary biodiversity with many endemic species, yet they are among the most threatened European communities with limited spatial distribution. These habitats are present in the Autonomous Province of Vojvodina in the north of Serbia, in the area of Srednja Mostonga, and they are in the procedure of protection as the II category protected area - "region of exceptional characteristics". Great variety of rare and endemic species makes this area interesting for recreational and educational activities. In this paper we investigate micrometeorological and outdoor thermal comfort conditions in different natural environments at the area of Srednja Mostonga. This is the first micrometeorological field measurement study conducted in this region. Measurements were performed during the daytime of a sunny autumn day in 2019. The results showed that daytime air temperature was up to $3.4^{\circ} \mathrm{C}$ lower in forest compared to steppe, while relative humidity was up to $5-6 \%$ higher in forest than in steppe with up to $3.2 \mathrm{~m} / \mathrm{s}$ lower wind speeds in forest than in steppe area. Micrometeorological values were similar between forest-steppe and steppe. However, the outdoor thermal comfort conditions expressed via Humidex showed that 'some discomfort' was most often observed in forest-steppe during $27 \%$ of measurement time, followed with $13 \%$ of 'some discomfort' observed in steppe and only $1 \%$ of 'some discomfort' was observed in forest. Accordingly, during the warmest daytime hours outdoor activities could be performed in forest, while early morning and evening hours could be spent in steppe and forest-steppe areas of Srednja Mostonga.
\end{abstract}

Keywords: temperature; humidity; Humidex; saline steppe; forest-steppe; forest; Serbia

\section{Introduction}

Saline habitats such as saline steppes and marshes of Pannonian plain in Serbia are strongly impacted by Pannonian climatic conditions characterized by extreme temperatures and aridity in summer. These areas are characterized by lower salt content, but higher alkalinity, and they have been present in the Carpathian Basin since the last Ice Age. These habitats have specific vegetation, with salt resistant plants, and they occur only in a few other countries in Europe (e.g. Hungary, Austria, Bulgaria, Romania, Slo-

A Climatology and Hydrology Research Centre, Faculty of Sciences, University of Novi Sad; Trg Dositeja Obradovića 3, 21000 Novi Sad, Serbia

B Department of Geography. Tourism and Hotel Management, Faculty of Sciences, University of Novi Sad; Trg Dositeja Obradovića 3, 21000 Novi Sad, Serbia

* Corresponding author: Dragan Milošević; e-mail: dragan.milosevic@dgt.uns.ac.rs 
vakia). They are considered to be among the most threatened European communities, due to their limited geographical distribution. Molnár et al. (2012) predicted transformation and fragmentation of saline habitats in Hungary, as well as decline of their resilience and recovery potential. Even though alkali plant communities are relatively poor regarding the species, their combinations are very specific and diverse. Saline habitats with their mosaic structures give the basis for extraordinarily rich flora and fauna, which contain endemic species (Šefferová Stanová et al., 2008).

Even though saline habitats are of great importance and should be priority areas for protection as recommended by the European Union (e.g. Directive 92/43/ EEC), that wasn't the case in Serbia until recently. In Vojvodina Province in northern Serbia, especially in Bačka region, there are large, yet fragmented areas of saline habitats (e.g. saline steppes, forest-steppes, forests) with rare and endemic wild species of national and international importance. Therefore, Institute for Nature Conservation of Vojvodina Province initiated protection of "Srednja Mostonga", as the natural area of II (second) category - region of exceptional characteristics (IUCN Category V: Protected Landscape/Seascape). Parts of the area of "Srednja Mostonga" have been singled out as an International Important Plant Area (IPA) and International Important Bird Area (IBA), as stated by the Ministry of Environment of the Republic of Serbia.

The main reasons for this initiative are many issues threatening saline habitats such as: agricultural activities, forest degradation, littering as well as climate change which affects fragile habitats like these. On the other hand, the conservation of the saline habitats could contribute to a number of positive activities and be beneficial for surrounding local communities. Protection initiatives are important for realization of sustainable tourism goals (Stojanović et al., 2018). Rare and endemic wild species which are internationally recognized (IPA and IBA areas) make this area interesting for ecotourism, which focuses on educational, cultural and community beneficial activities (Šiljeg et al., 2019). Since touristic activities based on natural resources often mean spending a great amount of time outdoors, they are strongly dependent on climatic conditions (Mihăilă \& Bistricean, 2018), and comfortable climatic conditions could enhance them. Scott et al. (2011) emphasized the importance of the climate conditions for the tourism sector, both destination management and visitors. Basarin et al. (2014) analyzed bioclimate of two special nature reserves in Serbia based on measurements from nearby stations and came to similar conclusions.

Measurements of microclimatic conditions in different natural saline habitats aims to contribute to the micrometeorological and outdoor thermal comfort assessment in order to make suggestions about the most suitable period for exploring or visiting these areas. The most important meteorological parameters influencing human outdoor thermal comfort are: air temperature, humidity, wind speed and global radiation. Combining the effect of air temperature and humidity on humans can be assessed with thermal comfort indices, such as Humidex (Masterton \& Richardson, 1979). This index was used to analyse thermal comfort conditions in numerous natural and urban areas (Błażejczyk \& Twardosz 2010; Orosa et al., 2014; Ramezani \& Fallahzadeh, 2014; Mekis et al. 2015; Tahbaz, 2018; Geletič et al. 2018; Garcia, 2019), due to its higher accessibility of input data when compared to other indices.

The main aims of this paper are threefold. Firstly, we wanted to perform the first field micrometeorological measurements in various natural environments of Srednja Mostonga consisting of saline steppe, forest-steppe and forest environments. Secondly, we wanted to investigate micrometeorological conditions and outdoor thermal comfort in their natural environments during a clear and sunny autumn day. And thirdly we wanted to assess and quantify micrometeorological and outdoor thermal comfort differences between saline steppe, forest-steppe and forest as the basis for sustainable natural protection and tourism activities.

\section{Study area, data and methods}

\section{Study area}

Srednja Mostonga (3,131 ha) is located in the northern part of Serbia (Vojvodina Province) on the territory of three municipalities: Apatin, Sombor and Odžaci. This area is highly influenced by saline soils due to high groundwater levels and continental climate. For this exact reason, the area of Srednja Mostonga has never been plowed in the past. The natural habitats are well preserved throughout this area unlike its sur- roundings where such features are permanently lost. Therefore, Srednja Mostonga has been proposed for protection based on the conservation study, which was written in 2018 by the experts of Institute for $\mathrm{Na}$ ture Conservation of Vojvodina Province.

There are 27 habitats of high priority protection in the area of Srednja Mostonga. Next, 17 habitats are within the priority NATURA 2000 internationally significant habitats (Conservation study, 2018). In 


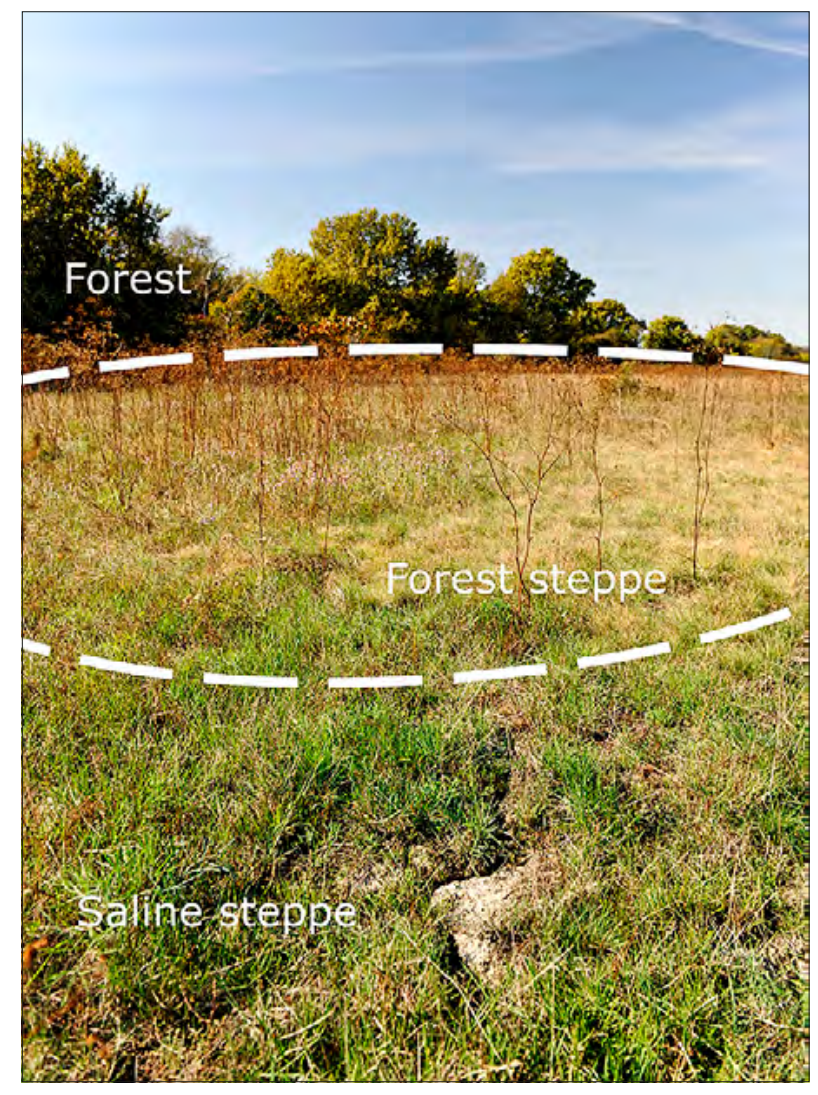

Figure 1. A range of habitats in "Srednja Mostonga": saline steppe, forest steppe and oak forest on the saline soils Photo: V. Stojanović

the triangle of the villages of Srpski Miletić, Bogojevo, Karavukovo - Donjaslatina location, there is a relatively small area characterized by more of habitats, ranging from saline to oak forests on the saline soils (Figure 1).

General long-term climate characteristics of the area of Srednja Mostonga can be assessed with data from meteorological station of Sombor $\left(45^{\circ} 46^{\prime} \mathrm{N} 19^{\circ}\right.$ o9' E, $88 \mathrm{~m}$ a.s.l.). This is the closest official meteorological station to the area of interest ( $25.3 \mathrm{~km}$ away). Unfortunately, there is no permanent meteorological station deployed in Srednja Mostonga area, which is a drawback if we want to access the climate change effects in this protected natural area in the future. Fortunately, Sombor meteorological station is located in a natural surroundings bordering the suburban area. This region has a Cfb climate (temperate climate, fully humid, and warm summers, with at least four $\mathrm{T}_{\text {mon }} \geq$ $+10^{\circ} \mathrm{C}$ ), according to the Köppen-Geiger climate classification (Kottek et al. 2006). The mean monthly air temperature ranges from $-0.1{ }^{\circ} \mathrm{C}$ in January to $21.9^{\circ} \mathrm{C}$ in July. The mean annual precipitation is $612 \mathrm{~mm}$ (Figure 2). Average wind speeds are from $1.7 \mathrm{~m} / \mathrm{s}$ for SSW direction to $3.1 \mathrm{~m} / \mathrm{s}$ for $\mathrm{N}$ direction. Data is obtained from Republic Hydrometeorological Service of Serbia for the 1981-2020 period.

We have performed the first micrometeorological measurements in Srednja Mostonga. The measurements were performed during a clear and sunny day of 21st October 2019 which could be representative of an ideal day for touristic activities in the area. October is characterized by decrease in precipitation and increase in relative humidity with average maximum temperatures $\left(T_{\max }\right)$ reaching $18.1^{\circ} \mathrm{C}$ (Figure 2) and

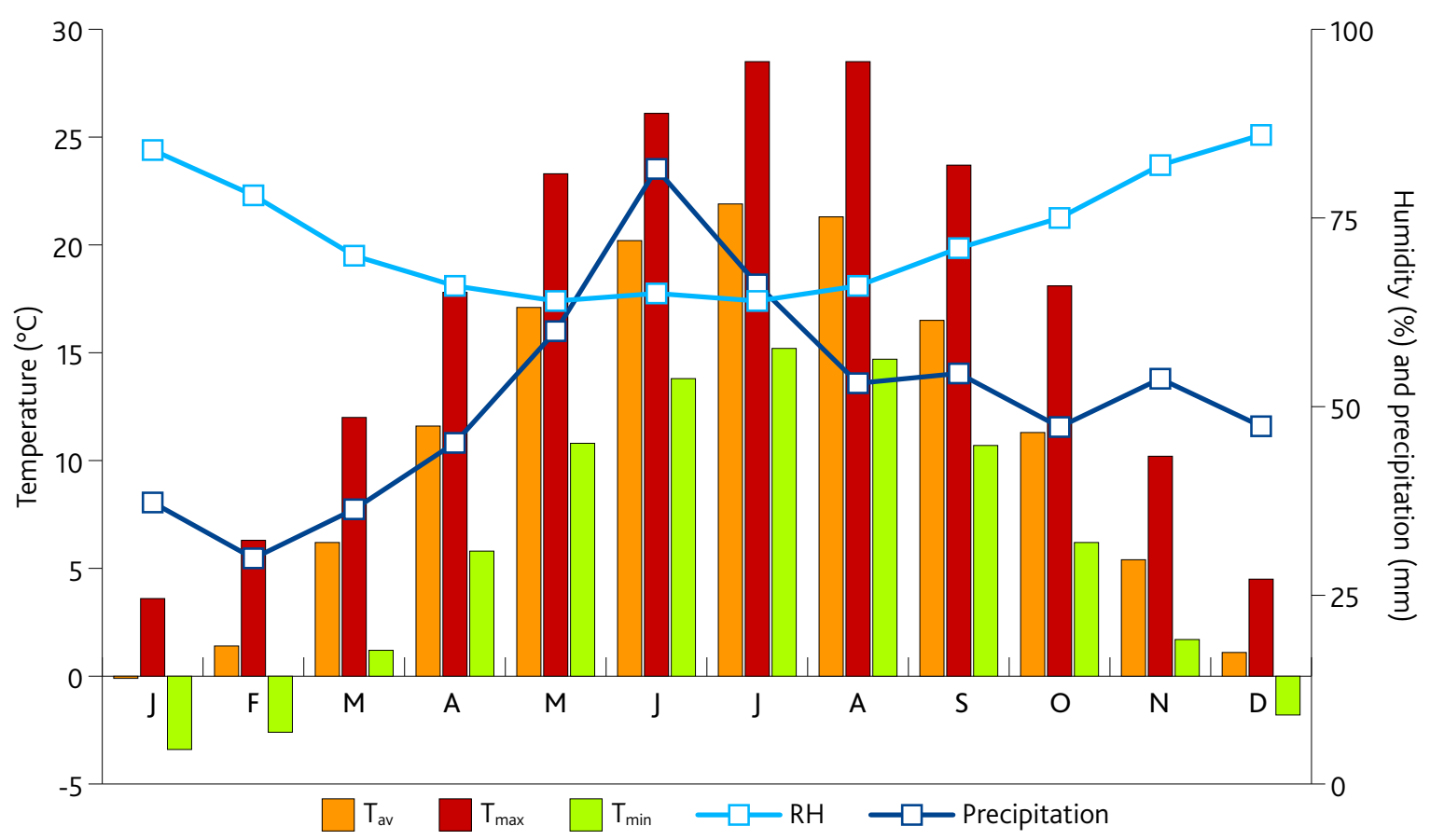

Figure 2. Climate data from Sombor meteorological station for the normal climatological period 1981-2010. Data obtained from Republic Hydrometeorological Service of Serbia. NOTE: Black rectangle shows the month in which we have performed measurements 
this month could be ideal for tourism (Eslami \& Tirandaz, 2011) due to comfortable air temperature during the midday hours with lower $T_{\max }$.

\section{Data and Methods}

For the present study, we have performed field micrometeorological measurements at three locations: saline steppe, forest-steppe and forest (Figure 3). The measurement campaign started at about 10:00 AM and lasted until about 3:30 PM on a clear and sunny autumn day (2 $1^{\text {st }}$ October 2019$)$. We have selected morning and midday hours to perform the measurements because during these hours with low wind speeds and lack of cloud cover, specific micrometeor- ological conditions in each investigated environment can be expected to develop and prevail. Furthermore, outdoor activities in this area are generally performed during the selected hours.

We used three mobile Kestrel 5400 Heat Stress Trackers (Figure 4$)$ to measure air temperature $\left(T_{a}\right)$, relative humidity $(R H)$, wind speed $(v)$ and globe temperature $\left(T_{g}\right)$ with one-minute measurement resolution. The measurements were performed at approximately $1.1 \mathrm{~m}$ height representing the center of gravity of the human body for standing subjects (ISO 7726 1998). The accuracy of instruments comply with ISO 7726 (1998) standards for sensor measurement range and accuracy (Table 1). In further analysis we used $T_{a}$,

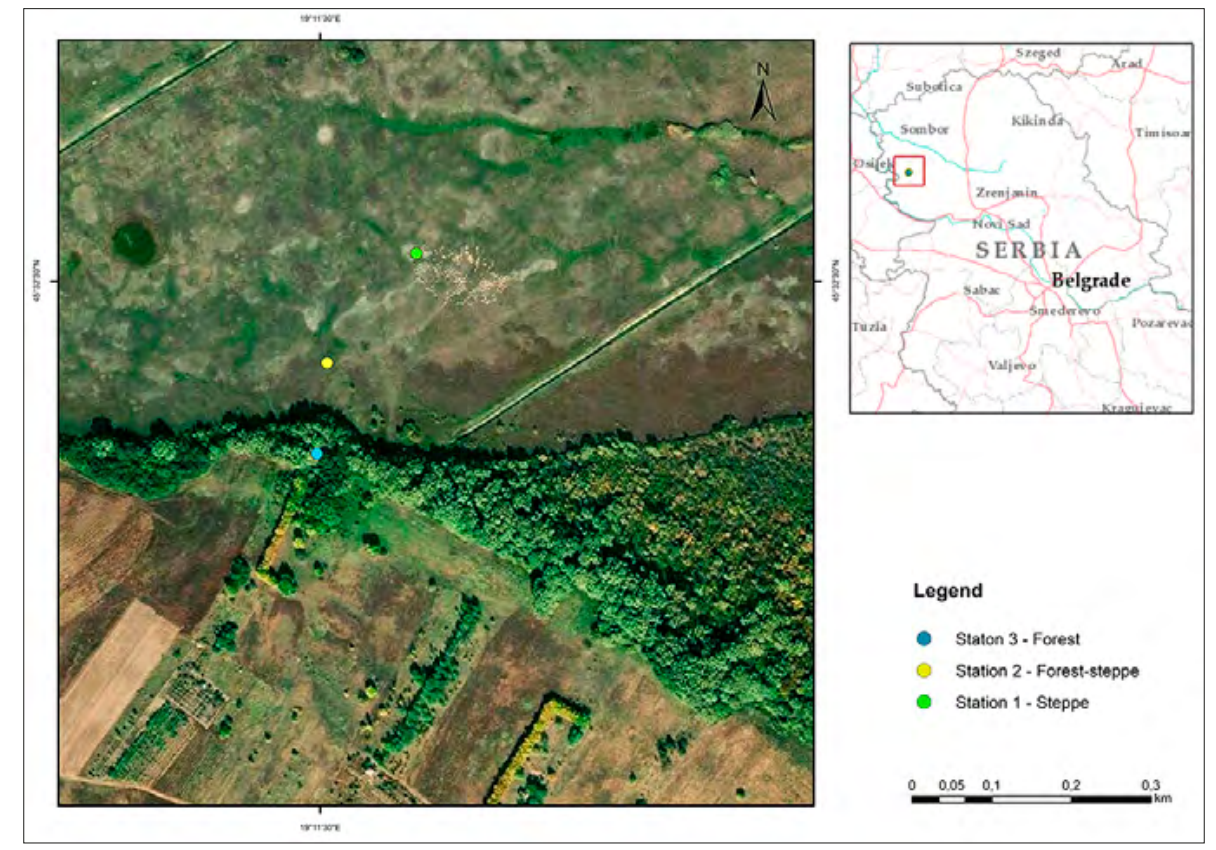

Figure 3. Measurement sites in Srednja Mostonga (Serbia) with the position of stations in saline steppe, forest-steppe and forest on $21^{\text {st }}$ October 2019
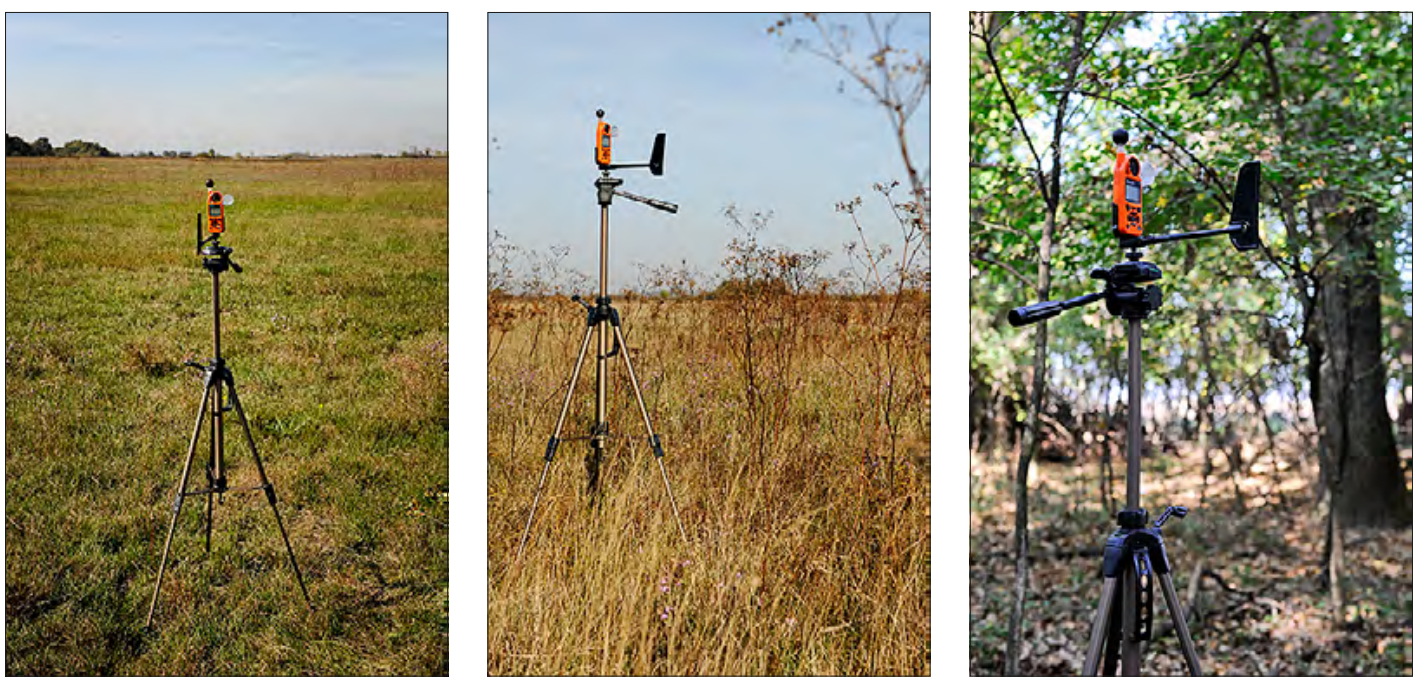

Figure 4. Instrumental set-up of the meteorological stations in: saline steppe, forest-steppe and forest (from left to right)

Photo: V. Stojanović 
Table 1. Sensor specifications for Kestrel 5400 Heat Stress Tracker used for the micrometeorological measurements

\begin{tabular}{|l|c|c|c|l|}
\hline Sensor & Accuracy (+/-) & Resolution & Range & \multicolumn{1}{c|}{ Notes } \\
\hline $\begin{array}{l}\text { Air } \\
\text { temperature }\end{array}$ & $0.5^{\circ} \mathrm{C}$ & $0.1^{\circ} \mathrm{C}$ & $\begin{array}{c}-29.0 \text { to } \\
70.0^{\circ} \mathrm{C}\end{array}$ & $\begin{array}{l}\text { Airflow of } 1 \mathrm{~m} / \mathrm{s} \text { or greater provides fastest response and } \\
\text { reduction of insolation effect. For greatest accuracy, avoid } \\
\text { direct sunlight on the temperature sensor and prolonged } \\
\text { sunlight exposure to the unit in low airflow conditions. }\end{array}$ \\
\hline $\begin{array}{l}\text { Relative } \\
\text { humidity }\end{array}$ & $\pm 2 \% \mathrm{RH}$ & $0.1 \% \mathrm{RH}$ & $\begin{array}{c}10 \text { to } 90 \% \\
25^{\circ} \mathrm{C} \text { non- } \\
\text { condensing }\end{array}$ & $\begin{array}{l}\text { To achieve stated accuracy, unit must be permitted to } \\
\text { equilibrate to external temperature when exposed to large, } \\
\text { rapid temperature changes and be kept out of direct sunlight. } \\
\text { Calibration drift is typically less than } \pm 0.25 \% \text { per year. }\end{array}$ \\
\hline Wind speed & $\begin{array}{c}\text { Larger of } 3 \% \text { of read- } \\
\text { ing, least significant } \\
\text { digit or } 20 \mathrm{ft} / \mathrm{min}\end{array}$ & $0.1 \mathrm{~m} / \mathrm{s}$ & $\begin{array}{c}0.6 \text { to } 40.0 \\
\mathrm{~m} / \mathrm{s}\end{array}$ & $\begin{array}{l}25 \text { mm diameter impeller with precision axle and low- } \\
\text { friction Zytel }{ }^{\circledR} \text { bearings. Startup speed stated as lower } \\
\text { limit, readings may be taken down to } 0.4 \mathrm{~m} / \mathrm{s}\end{array}$ \\
\hline
\end{tabular}

$R H$ and $v$ data and omitted $T_{g}$ due to numerous missing values. We have analyzed data from $11 \mathrm{AM}$ to 3 $\mathrm{PM}$, and omitted the first 30 to 45 minutes of measurements due to the acclimatization of the instruments. The recorded values were averaged at 5-min intervals and used in the further analysis.

Based on $T_{a}$ and $R H$, we have calculated Humidex, a biometeorological and outdoor thermal comfort index, developed by Masterton and Richardson (1979). The advantage of using this index is that only two meteorological elements are needed for calculation making the index widely understood by the public. The disadvantages are that wind speed and mean radiant temperature are not included in the calculation.

Humidex $(\mathrm{H})$ calculation was based on the Masterton and Richardson (1979) formula:

$$
H=T_{\text {air }}+\frac{5}{9}\left(6.112 \cdot 10 \frac{7.5 \cdot T_{\text {air }}}{237.7+T_{\text {air }}} \cdot \frac{R H}{100-10}\right)
$$

However, the calculation procedure itself was performed in Excel using formula transcribed by $\mathrm{Vy}$ soudil et al. (2016):

$$
H=\frac{\operatorname{POWER}\left(2.71828,23.58-\frac{4044.2}{235.6+T_{\text {air }}}\right)}{100 \cdot\left(\frac{R H}{100}-10\right) \cdot \frac{5}{9}+T_{\text {air }}}
$$

The range of Humidex values and the associated degree of comfort is given in Table 2. It can be seen that there is no discomfort when Humidex is less than 29. If Humidex is from low 30 s to high 30 , certain types of outdoor exercise could be performed at a slower pace or modified, depending on the age and health of the individual, physical condition, clothes characteristics, and other weather conditions. Great discomfort with possible dangerous health consequences can happen when Humidex values are above 40. All unnecessary activities should be stopped in such conditions (McGregor et al., 2015).

Table 2. Humidex values and degrees of comfort

\begin{tabular}{|l|l|}
\hline HUMIDEX values & Degree of comfort \\
\hline Less than 29 & no discomfort \\
\hline 30 to 39 & some discomfort \\
\hline 40 to 45 & great discomfort, avoid exertion \\
\hline Above 45 & dangerous \\
\hline Above 54 & heatstroke imminent \\
\hline
\end{tabular}

\section{Results and discussion}

We have observed micrometeorological differences between saline steppes, forest-steppes and oak forest in Srednja Mostonga region during the sunny autumn day. The highest $T_{a}$ are noticed in more open areas of forest steppe and steppe, while the lowest $T_{a}$ are observed in oak forest, as expected (Table 3). Although the forest area is small and it is a fragment of previously much larger forested area, it is still able to lower $T_{a}$ up to $3.4{ }^{\circ} \mathrm{C}$ (Figure 5) when compared to steppe area during the afternoon hours. Similar re- sults were obtained by Erdős et al. (2014) in southern Hungary. Differences in mean $T_{a}$ between forest and forest-steppe are $1.3^{\circ} \mathrm{C}$. On the contrary, small $T_{a}$ differences $\left(<0.5^{\circ} \mathrm{C}\right)$ are obtained between forest-steppe and saline steppe (Figure 5). This is because the forest-steppe is more similar to steppe than to forest area, because it does not contain trees, yet higher and lower grass species. It is discussed among the researchers that altered microclimatic conditions within the forest patches (Tuff et al. 2016) and forest fragmenta- 
tion is an important driver of biological impoverishment worldwide (Haddad et al. 2015). Due to that, it is important to preserve, improve and responsibly manage small forest fragments in Srednja Mostonga in order to save and improve its biodiversity and usage in the future. In order to do it, we need more measurement campaigns of air temperature and other parameters in fragmented forests, which was rarely done before (Arroyo-Rodríguez et al. 2017).

Highest $\mathrm{RH}$ is noticed in the forest as the most vegetated and "coldest" measurement location, while $R H$ was lowest in forest steppe (Table 3). Maximum $R H$ differences were up to 5-6\% between steppe and two other locations (Figure 6). Similar results were obtained by Chen et al. (1993) and Magnago et al. (2015) who pointed out that relative humidity was lower at forest edges compared to the forest interior. This can be problematic because the combination of lower humidity and increased air temperatures can contribute to tree mortality at forest edges (Kapos, 1989; Laurance et al. 2001) and this should be taken into account when managing Srednja Mostonga region.

The measurement day was characterized by low wind speeds at all three locations (Table 3). The $\mathrm{v}$ was highly variable, yet the wind averaged over measurement period followed the pattern with the highest $\mathrm{v}$ in steppe and the lowest in forest. Forest-steppe had
Table 3. Statistical characteristics of $T_{a}, \mathrm{RH}, \mathrm{v}$ and Humidex at three measurement locations in Srednja Mostonga during $21^{\text {st }}$ October 2019 (period 11 AM to 3 PM)

\begin{tabular}{|l|r|r|r|r|}
\hline Station & \multicolumn{1}{|l|}{ Ta } & \multicolumn{1}{|l|}{ RH } & v & Humidex \\
\hline Average values \\
\hline I saline steppe & 24.8 & 50.2 & 2 & 27.9 \\
\hline II forest steppe & 25.3 & 48.4 & 1.5 & 28.4 \\
\hline III forest & 24.0 & 50.4 & 0.6 & 26.7 \\
\hline Max. values \\
\hline I saline steppe & 29.3 & 59.6 & 3.9 & 32.7 \\
\hline II forest steppe & 29.4 & 59 & 3.5 & 33.2 \\
\hline III forest & 27.4 & 61.4 & 1.7 & 30.4 \\
\hline Min. values & \multicolumn{5}{|l|}{} \\
\hline I saline steppe & 20.5 & 38.4 & 0 & 22.7 \\
\hline II forest steppe & 20.7 & 37.3 & 0 & 23.1 \\
\hline III forest & 19.6 & 41.3 & 0 & 21.8 \\
\hline St. Deviation & & & \\
\hline I saline steppe & 2.1 & 6.4 & 0.7 & 2.1 \\
\hline II forest steppe & 2.2 & 6.1 & 0.7 & 2.3 \\
\hline III forest & 2.0 & 5.8 & 0.4 & 2.2 \\
\hline
\end{tabular}

higher $\mathrm{v}$ compared to forest, and values were similar as in steppe. The largest differences were obtained between steppe and forest with up to $3.2 \mathrm{~m} / \mathrm{s}$ higher $\mathrm{v}$ in steppe (Figure 7). Similar results were obtained

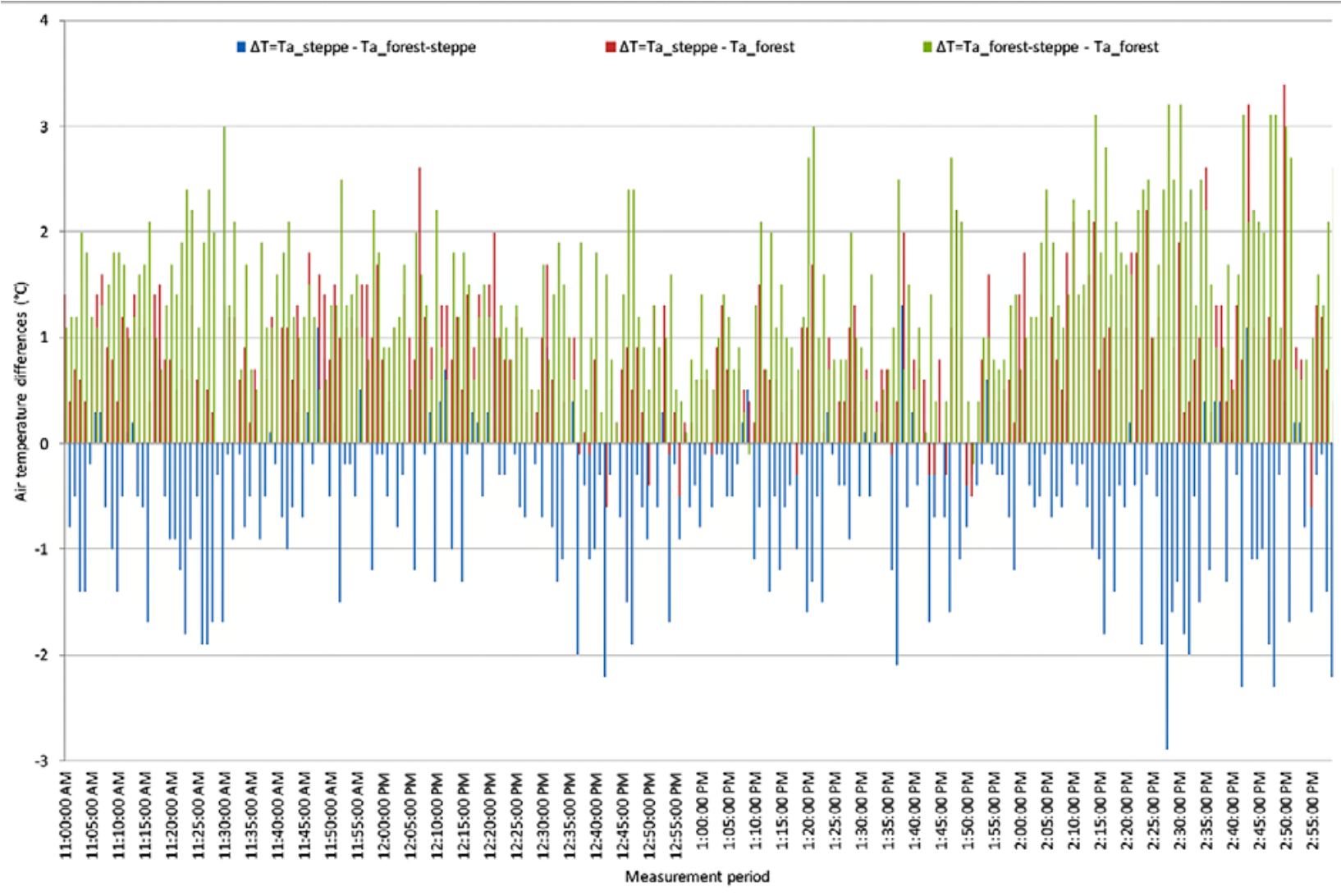

Figure 5. Air temperature differences between stations in steppe, forest-steppe and forest in Srednja Mostonga on 21 ${ }^{\text {st }}$ October 2019 


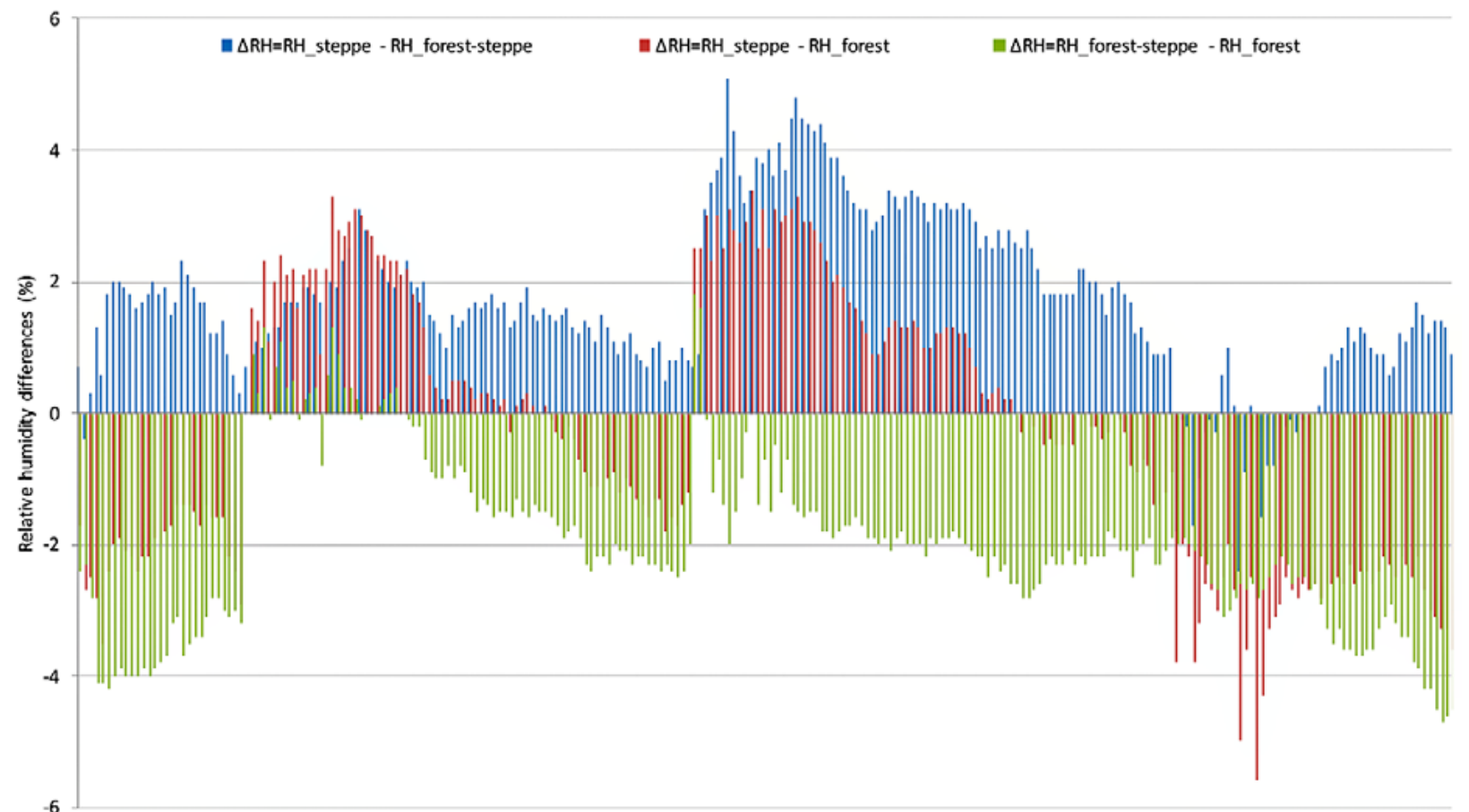

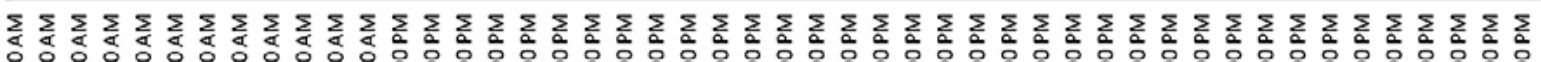

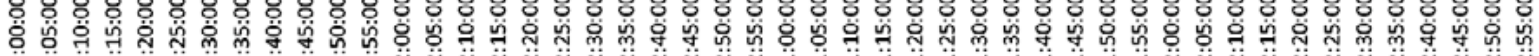

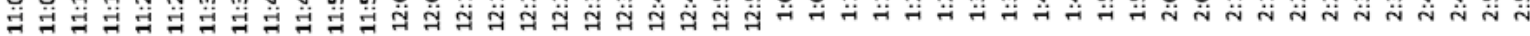

Measurement period

Figure 6. Relative humidity differences between stations in steppe, forest-steppe and forest in Srednja Mostonga on 21 ${ }^{\text {st }}$ October 2019

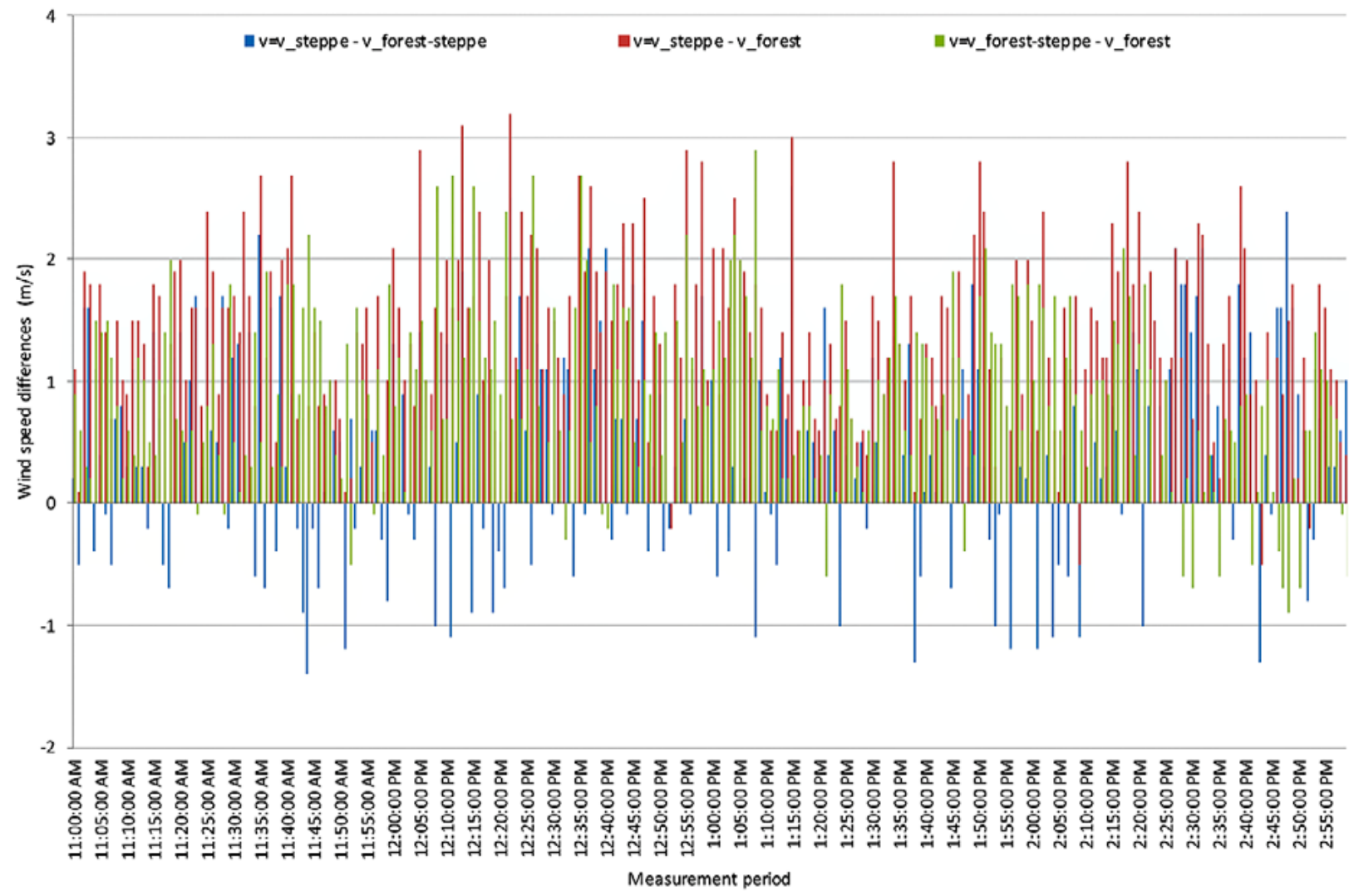

Figure 7. Wind speed differences between stations in steppe, forest-steppe and forest in Srednja Mostonga on $21^{\text {st }}$ October 2019 
by Davies-Colley et al. (200o) who pointed out that $\mathrm{v}$ was higher in pasture than in forest with the ratio of wind in forest to that in pasture (Mean \pm SE) averaged $10 \pm 3 \%$ in summer. Schindler et al. (2012) noticed that the interactions between airflow and trees and forest stands are quite diverse and include the reduction in near surface wind speed and production of turbulence by trees. As a consequence, near-surface wind conditions affect physiological processes in trees, their growth and survival (Ennos 1997; Eugster 2008). Accordingly, it is important to study the inter- actions between wind and forests in order to preserve its health and ecosystems services.

Analysis of the outdoor thermal comfort with the usage of Humidex showed that its lowest values are in the forest making it the most comfortable area for human activities (Table 3, Figure 8). On the contrary, forest-steppe and steppe have higher Humidex values. Forest-steppe location had on occasions Humidex values higher by 5 degrees compared to forest and steppe (Figure 8). Furthermore, some discomfort (Humidex between 30 and 39 ) was noticed during $13 \%$ of meas-

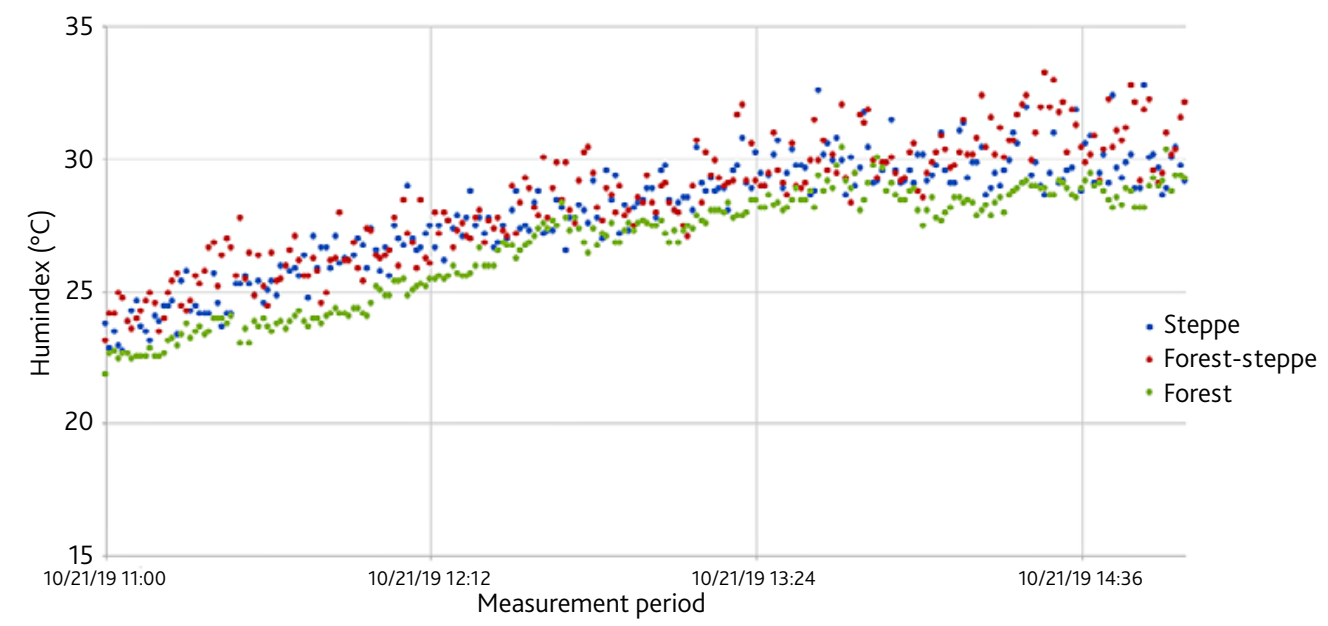

Figure 8. Humidex values in saline steppe, forest-steppe and forest in Srednja Mostonga on 21 $1^{\text {st }}$ October 2019 (period $11 \mathrm{~h}-15 \mathrm{~h}$ )

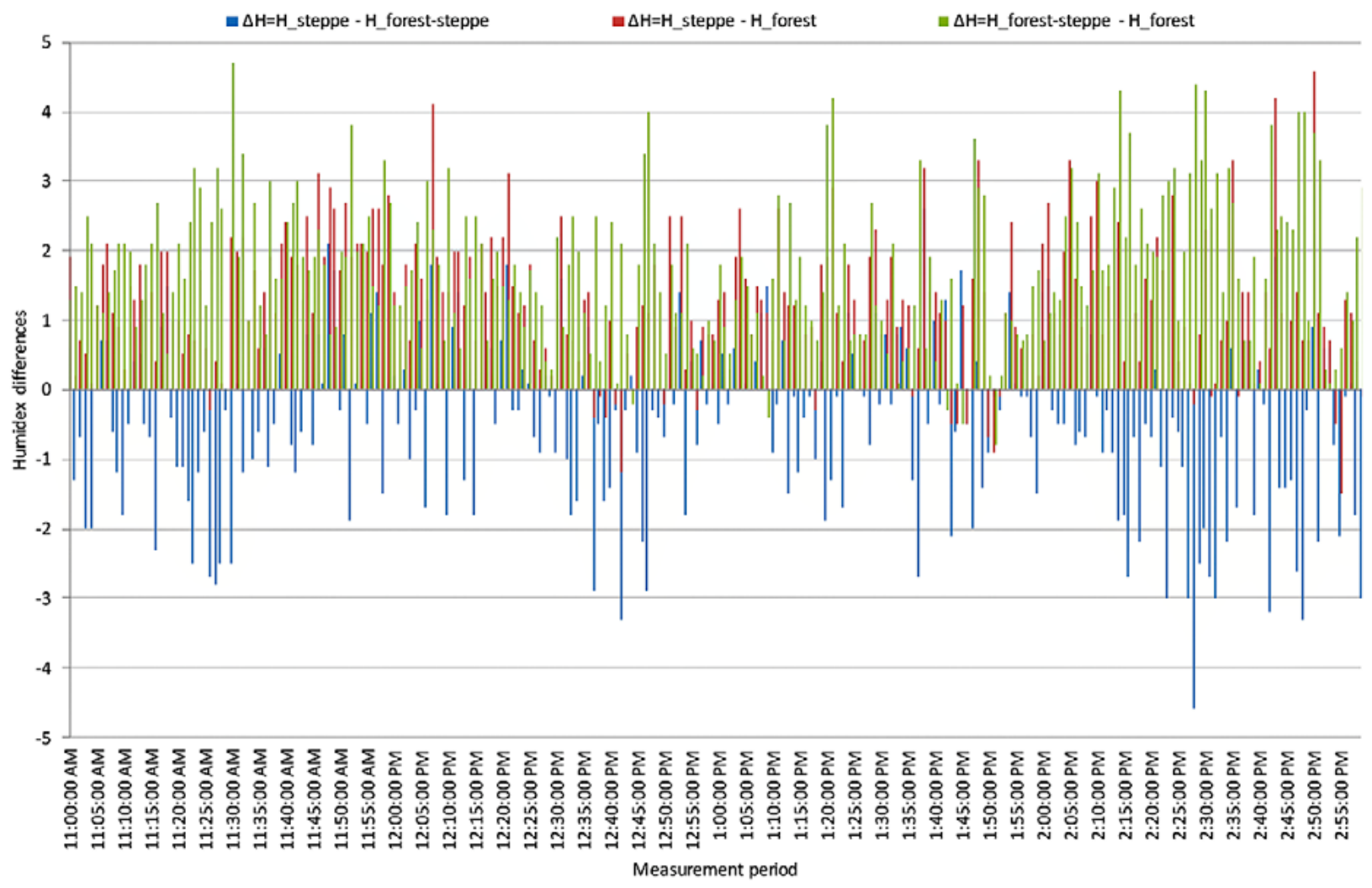

Figure 9. Humidex differences between stations in steppe, forest-steppe and forest in Srednja Mostonga on 21 ${ }^{\text {st }}$ October 2019 
urement time in steppe and $27 \%$ in forest-steppe making them less comfortable areas for outdoor touristic activities. In contrast, only $1 \%$ of measurement time in forest was characterized by some discomfort (Figure 9). Similarly, Kamoutsis et al. (2007) noticed that forest areas had a more comfortable climate with more frequent occurrence of "comfortable" weather compared to the nearby urban area. Even in the urban areas, high green coverage and low sky view factor lead to lower Humidex values (Charalampopoulos et al. 2013).

These results are important when planning tourist activities in these diverse natural areas. For example, during the warmest daytime hours touristic activities should be performed in forest, while early morning and evening hours (Figure 8) should be spent in steppe and forest-steppe. Although Humidex does not incorporate wind speed and mean radiant temperature into thermal comfort and heat stress assessment, its simplicity makes it easier to use by numerous practitioners which is an advantage when compared to other more complex indices.

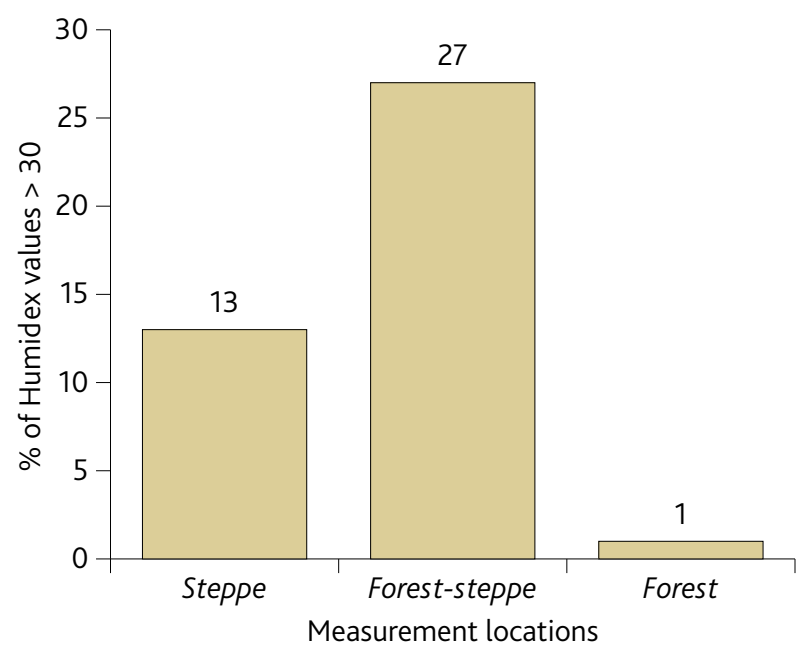

Figure 10. Frequency (\%) of Humidex values above 30 representing at least some discomfort in steppe, foreststeppe and forest in Srednja Mostonga on $21^{\text {st }}$ October 2019

\section{Conclusions}

The area of Srednja Mostonga, soon to be protected as the "region of exceptional characteristics", with its specific vegetation represents rather rare and significant habitat for the number of species. Since this area consists of rather vulnerable habitats, activities of any kind must be well planned and properly managed. In order to provide useful information for both destination management and interested visitors, we conducted initial measurements of microclimatic conditions in the area of Srednja Mostonga. Microclimatic measurements were performed in three different types of saline habitats (saline steppe, forest-steppe and forest) due to their different vegetation structure which affects microclimatic conditions.

The results of the initial short-term measurements showed that there are certain differences between microclimatic conditions in three different sites, even though the measurement stations were located at relatively short distance. Vegetation structure influences differences in air temperature, relative humidity and wind velocity, which affects thermal comfort. At the same time microclimatic conditions are affecting fragile saline species and habitats, by determining their ecological valences. Nature based recreational, educational and touristic activities require comfortable outdoor thermal conditions. In this study we used Humidex index for outdoor thermal comfort assessment. The results of outdoor thermal comfort assessment showed that the most comfortable thermal conditions are in the forest area during the entire measurement period, while the values of $\mathrm{Hu}$ midex showed slight discomfort in saline steppe and forest-steppe areas in the afternoon warmest hours. Maximum Humidex values show up to the $2.8 \mathrm{de}$ grees difference between forest (30.4), saline steppe (32.7) and forest-steppe areas (33.2). This information indicates that the activities in the investigated sights should be organized according to the most comfortable period of the day. For example, in the morning hours thermal conditions are more favorable at steppes and forest-steppes, and during the warmest period of the day, the conditions are more comfortable in the forest.

Micrometeorological measurements of this kind provide valuable information for tourism zoning and visitors distribution according to the most comfortable hours of the day, which contributes to sustainable management of tourism activities. Since this study is the first micrometeorological field measurement conducted in this region, even though it was a short-term measurement, it gave important insights into micrometeorological differences between different natural environments. In order to contribute to long-term strategic planning of the activities and their sustainable management, longer measurements during different seasons, measurement of nighttime meteorological values and soil temperatures (e.g. Lehnert et al., 2015) would be beneficial. 


\section{Acknowledgement}

The authors would like to acknowledge that this research was supported by the Provincial Secretariat for Higher Education and Scientific Research, Autonomous Province of Vojvodina (Project 142-451-2512/2019-01).

\section{References}

Arroyo-Rodríguez, V., Saldana-Vazquez, R. A., Fahrig, L., \& Santos, B. A. (2017). Does forest fragmentation cause an increase in forest temperature?. Ecological research, 32(1), 81-88.

Basarin, B., Kržič, A., Lazić, L., Lukić, T., Đorđević, J., JanićijevićPetrović, B., Ćopić, S., Matić, D., Hrnjak, I.\&Matzarakis, A. (2014). Evaluation of bioclimate conditions in two special nature reserves in Vojvodina (northern Serbia). Carpathian journal of earth and environmental sciences, 9(4), 93-108.

Błażejczyk, K., \&Twardosz, R. (2010). Long-term changes of bioclimatic conditions in Cracow (Poland). In The Polish Climate in the European Context: An Historical Overview (pp. 235-246). Dordrecht:Springer.

Charalampopoulos, I., Tsiros, I., Chronopoulou-Sereli, A., \&Matzarakis, A. (2013). Analysis of thermal bioclimate in various urban configurations in Athens, Greece. Urban Ecosystems, 16(2), 217-233.

Chen, J., Franklin, J. F., \& Spies, T. A. (1993). Contrasting microclimates among clearcut, edge, and interior of old-growth Douglas-fir forest. Agricultural and forest meteorology, 63(3-4), 219-237.

Davies-Colley, R. J., Payne, G. W., \& Van Elswijk, M. (2000). Microclimate gradients across a forest edge. New Zealand Journal of Ecology, 111-121.

EC Directive 92/43/EEC. On the conservation of natural habitats and of wild fauna and flora.

Ennos, A. R. (1997). Wind as an ecological factor. Trends in Ecology \& Evolution, 12(3), 108-111.

Erdős, L., Tölgyesi, C., Horzse, M., Tolnay, D., Hurton, Á., Schulcz, N., Körmöczi, L., Lengyel, A. \&Bátori, Z. (2014). Habitat complexity of the Pannonian forest-steppe zone and its nature conservation implications. Ecological Complexity, 17, 107-118.

Eslami, A. R., \&Tirandaz, M. (2011). The use of GIS on bioclimatic zoning for tourism settlement (case study: polroud basin, Guilan province). Annals of Biological Research, 2(5), 44-51.

Eugster, W. (2008). Wind effects. In: Jo"rgensen, S.E.,\&Fath, B.D. (eds). Ecological processes, vol. 5 of Encyclopedia of Ecology. Oxford:Elsevier, pp.3794-3803

García, M.C. (2019). Thermal Differences, Comfort/ Discomfort and Humidex Summer Climate in Mar del Plata, Argentina. In Urban Climates in Latin America (pp. 83-109). Springer, Cham.
Geletič, J., Lehnert, M., Savić, S., \&Milošević, D. (2018). Modelled spatiotemporal variability of outdoor thermal comfort in local climate zones of the city of Brno, Czech Republic. Science of the total environment, 624, 385-395.

Haddad, N.M., Brudvig, L.A., Clobert, J., Davies, K.F., Gonzalez, A., Holt, R.D., Lovejoy, T.E., Sexton, J.O., Austin, M.P., Collins, C.D.\& Cook, W.M. (2015). Habitat fragmentation and its lasting impact on Earth's ecosystems. Science advances, 1(2), e1500052. Institute for Nature Conservation of Vojvodina Province(2018).Conservation study - Outstanding Natural Landscape "Srednja Mostonga".

ISO 7726 (1998) Ergonomics of the thermal environment-instruments for measuring physical quantities. International Standard, 2nd edn. International Organization for Standardization (ISO), Geneva

Kamoutsis, A., Matsoukis, A., Charalampopoulos, I., \&Chronopoulou-Sereli, A. (2007). Biometeorological conditions in mountainous communities and adjacent urban center in Greece by the use of indices: The case study of mountainous Nafpaktia district. Developments in Tourism Climatology, 19-22.

Kottek, M., Grieser, J., Beck, C., Rudolf, B., \& Rubel, F. (2006). World map of the Köppen-Geiger climate classification updated. MeteorologischeZeitschrift, 15(3), 259-263.

Kapos, V. (1989). Effects of isolation on the water status of forest patches in the Brazilian Amazon. Journal of tropical ecology, 5(2), 173-185.

Laurance, W. F., Williamson, G. B., Delamônica, P., Oliveira, A., Lovejoy, T. E., Gascon, C., \& Pohl, L. (2001). Effects of a strong drought on Amazonian forest fragments and edges. Journal of Tropical Ecology, 17(6), 771-785.

Lehnert, M., Vysoudil, M., \& Kladivo, P. (2015). Semistationary measurement as a tool to refine understanding of the soil temperature spatial variability. International Agrophysics, 29(4), 449-457.

Magnago, L. F. S., Rocha, M. F., Meyer, L., Martins, S. V., \&Meira-Neto, J. A. A. (2015). Microclimatic conditions at forest edges have significant impacts on vegetation structure in large Atlantic forest fragments. Biodiversity and Conservation, 24(9), 2305-2318.

Masterton, J. M., \& Richardson, F. A. (1979). Humidex: a method of quantifying human discomfort due to 
excessive heat and humidity. Environment Canada, Atmospheric Environment.

McGregor, G. R., Bessmoulin, P., Ebi, K., \&Menne, B. (2015). Heatwaves and health: guidance on warningsystem development. WMOP.

Mekis, É., Vincent, L. A., Shephard, M. W., \& Zhang, $X$. (2015). Observed trends in severe weather conditions based on humidex, wind chill, and heavy rainfall events in Canada for 1953-2012. Atmosphere-Ocean, 53(4), 383-397.

Mihăilă, D., \&Bistricean, P. I. (2018). The Suitability of Moldova Climate for Balneary-Climatic Tourism and Outdoor Activities-A Study Based on the Tourism Climate Index. Present Environment and Sustainable Development, 12(1), 263-282.

Molnár, Z., Biró, M., Bartha, S., \& Fekete, G. (2012). Past trends, present state and future prospects of Hungarian forest-steppes. In Eurasian steppes. Ecological problems and livelihoods in a changing world (pp. 209-252). Dordrecht:Springer.

Orosa, J. A., Costa, Á. M., Rodríguez-Fernández, Á., \& Roshan, G. (2014). Effect of climate change on outdoor thermal comfort in humid climates. Journal of Environmental Health Science and Engineering, 12(1), 46.

Ramezani, B., \&Fallahzadeh, M. (2014). Assessment and analysis of thermal comfort based on bioclimatic indices. Case study: Port of Anzal-Iran. Journal of Applied Environmental and Biological Sciences, 4(1), 116-125.
Schindler, D., Bauhus, J., \& Mayer, H. (2012). Wind effects on trees. European Journal of Forest Research, 131,159-163

Scott, D. J., Lemieux, C. J., \& Malone, L. (2011). Climate services to support sustainable tourism and adaptation to climate change. Climate Research, $47(1-2), 111-122$.

ŠefferováStanová V., Janák M. \&Ripka J. (2008). Management of Natura 2000 habitats. $1530{ }^{*}$ Pannonic salt steppes and salt marshes. European Commission - Technical report 03/2

Šiljeg, A., Cavrić, B., Šiljeg, S., Marić, I., \&Barada, M. (2019). Land suitability zoning for ecotourism planning and development of Dikgatlhong Dam, Botswana. GeographicaPannonica, 23(2), 76-86.

Stojanović, V., Lazić, L., \&Dunjić, J. (2018). Nature protection and sustainable tourism interaction in selected Ramsar sites in Vojvodina (Northern Serbia). GeographicaPannonica, 22(3), 201-207.

Tahbaz, M. (2018). Microclimate Observation by Outdoor Thermal Indices (Case Study of Five Climates). International Journal of Architectural Engineering \& Urban Planning, 28(1), 49-70. DOI: 10.22068/ ijaup.28.1.49

Tuff, K. T., Tuff, T., \& Davies, K. F. (2016). A framework for integrating thermal biology into fragmentation research. Ecology letters, 19(4), 361-374.

Vysoudil, M., Lehnert, M., \& Kladivo, P. (2016). Heat stress in the urban and suburban landscape and its spatial differentiation through the example of a medium-sized city. Dela, (46), 163-182. 